I. V. FILIMONOVA ${ }^{1,2}$, Professor, Doctor of Economic Sciences, Filimonovalv@list.ru

S. M. NIKITENKO ${ }^{3}$, Professor, Doctor of Economic Sciences

I. V. PROVORNAYA ${ }^{3}$, Candidate of Economic Sciences

Yu. A. DZYUBA ${ }^{1,2}$, Junior Researcher

${ }^{1}$ Trofimuk Institute of Petroleum Geology and Geophysics, Siberian Branch, Russian Academy of Sciences, Novosibirsk, Russia

${ }^{2}$ Novosibirsk State University, Novosibirsk, Russia

${ }^{3}$ Institute of Coal, Federal Research Center for Coal and Coal Chemistry, Siberian Branch, Russian Academy of Sciences, Kemerovo, Russia

\title{
FORECAST OF REGIONAL STRUCTURE OF OIL PRODUCTION IN RUSSIA
}

\section{Introduction}

The oil industry is an important element of the global energy supply system. Oil is the main source of energy in the world and its consumption makes about $40 \%$ in the structure of the global fuel and energy balance [1]. This fact can be explained by the wide range of oil use, by its demand in various sectors of the economy (transport, energy, chemical industry, etc.), by the significant proven reserves, and also by the modern safety regulations in energy production and consumption systems.

In recent decades, the oil market has transformed in the direction of intensifying inter-fuel competition (the role of renewable energy sources is increasing due to environmental restrictions) [2] and regional differentiation. Regional differentiation in oil production and oil consumption is the main feature of the modern world, reflecting the polarity and unevenness of its development. The key event of the last decade, which had a significant impact on the change in regional proportions in oil production, was the beginning of the development of shale oil reservoirs in the United States. This factor significantly strengthened the country's position, made it one of the technological leaders in the hard to recover oil production sector, and also allowed it to influence the level of oil prices [3].

Russia also has the unique potential of "difficult" oil (tight oil), which is concentrated in the Arctic regions of the country, in Eastern Siberia region and in the Far East, as well as in the Bazhenov Formation of Western Siberia [4]. Commenced development of these reserves in the long term may become the basis for the technological re-equipment of the industry and have a positive effect on the rate of socio-economic growth of the entire country.

Oil production in Russia is the main source of the federal budget revenue generation, the guarantor of social stability, the driver of technological and innovative development and economic growth of the country during the last decades [5]. At the end of 2018, oil production in Russia grew by 9.0 million tons and amounted to 555.8 million tons, approaching the absolute maximum production of the former Soviet Russia since 1988 (570 million tons). The share of revenues from oil products in the form of mineral extraction tax (MET) and export duties in the structure of federal budget revenues increased to $35 \%$ in 2018.

At the same time, the main feature of the oil and gas sector development in Russia in recent decades is a change in the geography of production, with its transition to regions with harsh environmental and climatic conditions and poor infrastructure. Furthermore, the production of "difficult" oil grows, albeit at a slow pace due to the lack of necessary domestic technologies for the search, evaluation, exploration and production of tight oil $[6,7]$. That is why there is an objective need for a comprehensive study into stages of oil production transition and patterns of productive capacity distribution, with regard, among other things, to the peculiarities of oil and condensate production in the constituent entities of the Russian Federation and the country's oil and gas basins. This article explores prospects of the oil and gas sector and provides a long-term forecast of changes in geography of the oil industry in Russia. 
The role of the oil and gas sector in the Russian economy

The studies into the role of the oil and gas sector in the country's economy first appeared during the formation of the fourth technological order (the Oil Age). The intense competition for energy and the rising oil prices in the 1970s increased researchers' interest in analyzing and evaluating the role of oil production in the economies of individual countries. The pioneers in the analysis of the economic effect of changes in the oil and gas sector were American scientists [8-10], who analyzed the impact of sharp fluctuations in oil prices on the US economy. Later on, scientists investigated the influence of oil price fluctuations on the economy of various macro regions and countries [11-14].

Also in the mid-1970s and early 1980s, the studies into the economic advance in the regions with the prevailing oil and gas sector were initiated. J. Sachs and A. Warner [15] highlighted a slowdown in the development of countries with significant resource potential. In this respect, the concepts of "enclave type of development", "resource curse", "oil curse", "Dutch disease", etc. found widespread occurrence [16]. The authors $[15,16]$ emphasize the negative impact exerted by the mining industry expansion on the economies of developing countries holding huge natural resources. First of all, the adverse effect manifests itself in the strengthening of the real exchange rate of the national currency, which hinders the competitiveness of domestic goods and services in the world market, and also slows down technological, macroeconomic and institutional development. On the other hand, the more recent studies [17-19] subject the "resource curse" to valid criticism. The authors note that the benefit from the expansion of production is achieved due to the multiplicative effect in the conditions of sustained diversification of public revenues from the nonmining sector of the economy.

At the beginning of the 2000s, researches started to address various scenarios of the economy transition from a resource type of development to a resource-inertial one. The interest was rekindled due to rising world oil prices, as well as owing to the necessity to find effective directions of oil rent distribution and a new model for the development of the Russian economy to avoid the consequences of the "Dutch disease". Polterovich V. M., Popov V. V., Tonis A. S. [20] evolved the idea of institutional transformations required to overcome the "resource curse" and convert income from the export of raw materials into a source of socio-economic growth and advancement of economy in Russia.

Sustainable Russian and international trends in the oil and gas sector are the subject of the analysis undertaken by many research teams aimed to forecast the future oil market. The analytical reviews of the United States Department of Energy (EIA), International Energy Agency (IEA) and the Organization of Petroleum Exporting Countries (OPEC) have received sufficient popularity. The long-term forecasts of the development of the world energy by these organizations are also popular in the scientific community. Furthermore, oil production forecasts are published by major energy multinational companies such as Shell, Exxon Mobil and British Petroleum.

Large academic institutes and centers (such as the Energy Research Institute of the Russian Academy of Sciences (ERI RAS), Institute of Petroleum Geology and Geophysics (IPGG SB RAS), Melentiev Energy Systems Institute (ESI SB RAS), Institute of Economic Forecasting (IEF RAS), Institute of

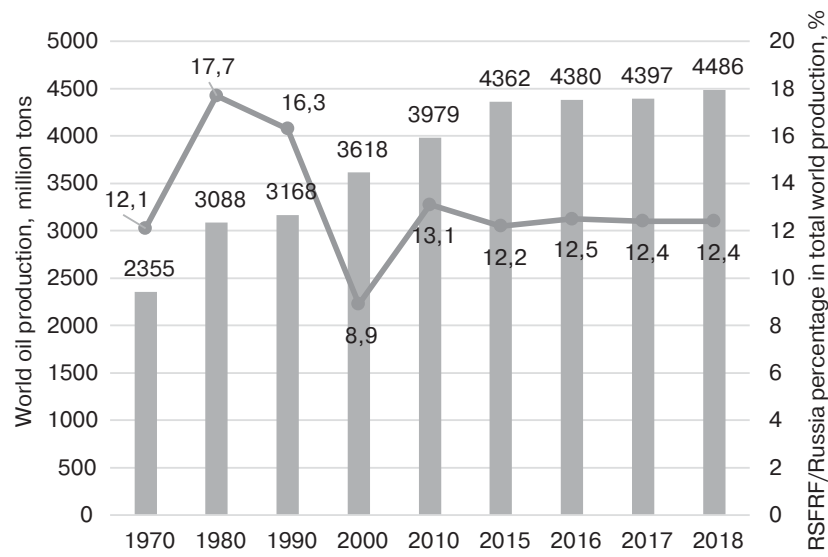

Fig. 1. World oil production in 2018

Economics and Industrial Engineering (IEIE SB RAS) and some others) develop methodological frameworks for forecasting oil production in Russia and for assessing the impact of the sector on the country's economy.

In terms of the fundamental approaches to forecasting oil production, three main levels can be distinguished: macrolevel, meso-level and micro-level. At the macro-level, the methodological approaches to forecasting oil production take into account the cross-influence of internal and external factors and use the models of the scale of the world economy or individual countries. The forecast of oil production at the meso-level, as a rule, creates the basis for planning the sectoral and socio-economic development of individual regions or groups of oil fields. The approaches to forecasting oil production at the micro-level are of interest to subsoil users since they assess the production potential of individual fields, reservoirs or wells. The simultaneous consideration of an object at different forecasting levels is enabled by the variety of existing tools.

\section{Retrospective analysis of oil production in Russia}

The world oil production in 2018 amounted to 4.5 billion tons, which is $2.2 \%$ more than in the previous year (Fig. 1). The increment in oil production in 2018 (94.5 million tons) was provided by the countries outside the group of OPEC, in particular, the United States, whose share in the annual growth reached almost $80 \%$. The U.S. oil production increases owing to the beginning of shale oil development, which is very sensitive to changes in oil prices. At the end of 2018 , oil prices rose to US\$ 85 per barrel, which was the main factor to spur oil companies to increase the number of drilling sites and, as a result, to enhance the production. Under favorable pricing conditions, oil production growth was observed in 2018 in Saudi Arabia and Russia, while other OPEC countries decreased the production by $0.5 \%$. At the end of 2018 , the share of OPEC countries in world oil production amounted to $41.3 \%$.

The Russian oil industry arose in the 19th century in Baku. Oil production in the territories adjacent to Baku was the world leader at the turn of the 19th and 20th centuries. The second promising region for oil production in the country was the Volga-Ural oil and gas province, which reached the peak in production around 1975 . The third-largest oil production center in the USSR was Western Siberia [21, 22].

The maximum level of oil production in Russia was reached in 1987 and totaled 570 million tons or $20 \%$ of the global value. 
After 1989, a gradual reduction in oil production began in the country due to going on the shelf and falling production in the unique and large fields discovered in the 1960s-70s in Western Siberia.

In the period of 1994-1999, oil production in the country remained at the level of 300-310 million tons, or $9-10 \%$ of the world production. The main cause for the decline in production was a break in economic ties and a change in the organizational structure of the industry. During mortgaging auctions in 1995, the main oil and gas producing plants of the Soviet Union were privatized, and the modern vertically integrated oil companies formed. As a result of the systemic crisis accompanied by high rates of inflation and depreciation of the national currency, the underfunding of many industries, including exploration, took place. Therefore, the natural depletion of large reservoirs in Western Siberia was only balanced after 2000, through the increase in reserves owing to new deposits in the Russian Far East and Eastern Siberia.

The increase in the world oil prices in 1999-2008 and the stabilization of the political and new organizational and economic conditions for the industry at the end of the 1990s allowed initiation of technological renewal [23]. Thanks to influx of high export earnings, companies began to form sources of investment in the production intensification technologies and in the exploration of new fields, which led to a rapid increase in oil production. In the period of 2000-2004, the annual increase was approximately $8-10 \%$.

Since the 2000s, the system of pipeline transportation of oil began to develop rapidly. An independent export route was built to supply Russian oil to consumers in North-Western Europe, bypassing the Baltic countries (Baltic Pipeline System (BPS-1 and BTS-2)). The Eastern Siberia-Pacific Ocean (ESPO) trunk pipeline in the line of Taishet-SkovorodinoKozmino, with branch pipelines Skovorodino-Mokhe and Kuyumba-Taishet was commissioned. The construction of the northernmost Arctic Circle-Purpe-Samotlor pipeline system was also completed. The port infrastructure for the delivery of oil and oil products by sea (Nakhodka, Primorsk, Novorossiysk, Tuapse, Ust-Luga, etc.) was significantly expanded and modernized.

The period of high oil prices, coupled with the active construction of transport infrastructure and improvement of tax legislation, launched the investment cycle in the industry: oil and gas companies began to attract funds in the development of oil reserves in Eastern Siberia and in the Far East of Russia, in the Arctic continental and offshore zones, as well as in mining of hard-to-recover reserves of Western Siberia [24]. Thus, oil production in the country over the past few years has been steadily growing and holding at the level of 550-560 million tons.

\section{Current oil production in Russia}

The largest regions of oil production in Russia, starting from the 1960-70s, are Western Siberia and Volga-Ural oil and gas provinces. For another thing, oil recovery is carried out in the Timan-Pechora and Northern Caucasus oil and gas provinces. In 2008, the Eastern Siberia-Pacific Ocean oil trunk pipeline was commissioned. This fact has become a powerful incentive for the development of the Lena-Tunguska and Okhotsk oil and gas provinces.

Oil fields in Western Siberia provide $57 \%$ of the total oil production in Russia. On the other hand, the fields feature high

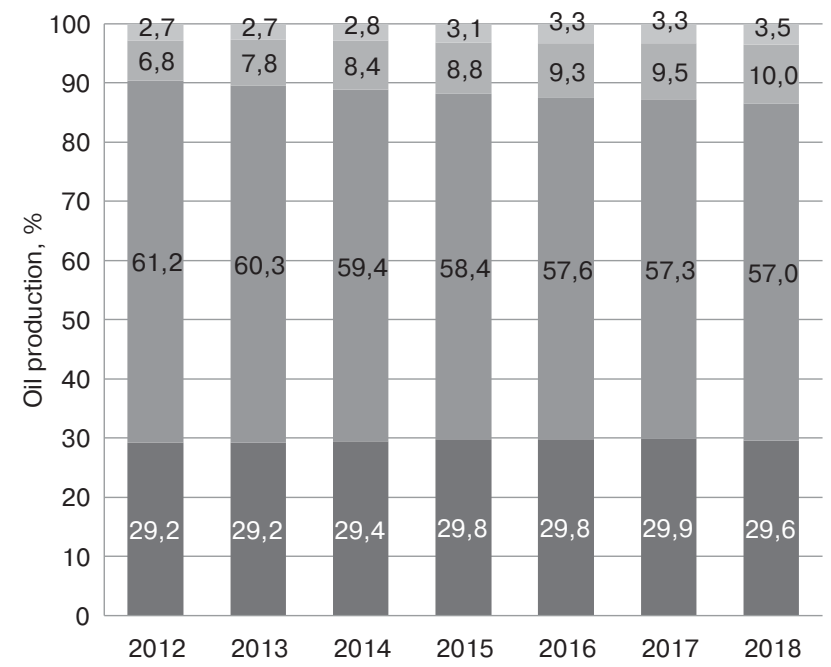

Far East Eastern Siberia and the Republic of Sakha (Yakutia)

Western Siberia $\quad$ European part of Russia

\section{Fig. 2. Regional structure of oil production in Russia}

depletion and water cut to $80-90 \%$; so the share of the region, mainly Khanty-Mansi Autonomous Okrug, reduces gradually in oil output in Russia. At the same time, profitability of the oilfield development lowers and oil companies regularly apply to the Government of the Russian Federation for additional benefits to stimulate production and investment in the methods of maintenance of reservoir pressure and enhancement of oil recovery (Fig. 2).

Oil production in the European part of Russia has stabilized since 2012 and slightly grew henceforth. The share of the region in the total oil output in Russia is about $30 \%$. The increase in the output of the traditional oil production centers in the European part of Russia (Tatarstan, Bashkortostan, Orenburg Oblast, etc.) became possible due to the active use of new technologies for the extraction of oil with peculiar physicochemical properties (viscous, dense, and sulfurous).

Since 2008, the Russian Far East and Eastern Siberia had become the new center of oil production in the country, providing up to $10 \%$ of the annual increase in national oil output. Production is performed in the three major oil fields-Vankor (Krasnoyarsk Krai), Verkhnechonsk (Irkutsk Oblast) and Talakan (Republic of Sakha (Yakutia)). In recent years, due to active subsoil use along the ESPO route, new oil reservoirs are put into operation.

\section{Technological features of oil production in Russia}

The main characteristics of the technological development in the industry are the operating well stock and derivatives (percentage of idle wells, penetration of wells, average flow rate, etc.), reflective of the steady trends and regular patterns in industrial expansion of the Russian oil and gas sector. The operating well stock is divided into active and inactive wells, and the latter include wells that have been in operation for at least a short time in the reporting period.

In 2018 the operating well stock amounted to 177 thousand wells, which is 2 thousand more than in 2017. Since 2009 the number of the operating wells increased annually by an average of $2 \%$, except for the drop in 2015 during the crisis period (Fig. 3). 


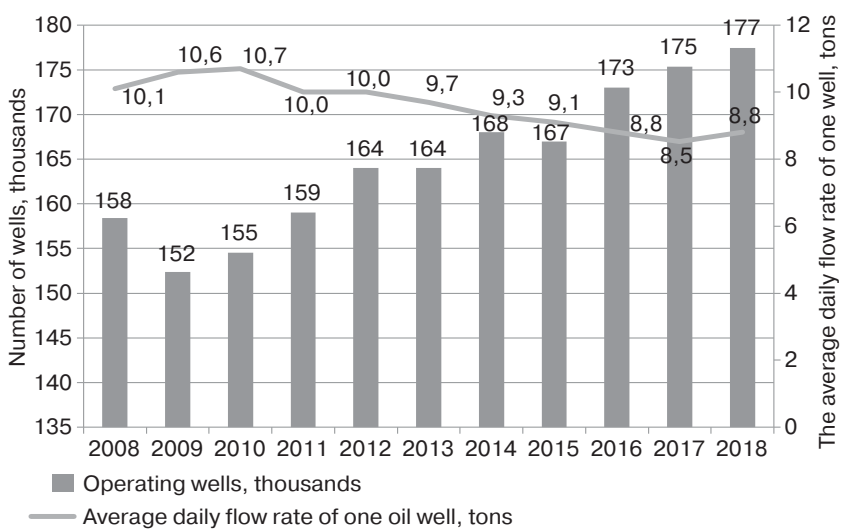

Fig. 3. Operating well stock and average daily production rate

However, due to the quality deterioration and depletion of field reserves, the average daily production rate of one oil well has been steadily declining in the last 10 years, from 10.6 tons in 2009 to 8.5 tons in 2017 . In 2018 the average daily flow rate increased to 8.8 tons of oil.

The inactive stock includes wells out of operation for more than one calendar month either in the present or previous years. In 2018 idle wells made the minimum percentage for the entire considered period-8.3\% (14.8 thousand wells). From 2008 to 2018 , the dynamics of the idle stock was unstable, although, there was a general trend toward a two-fold decrease in percentage of idle wells in the total operating well stock.

Putting of oil wells into production. In 2018, 7946 new wells were put in production in Russia, which was less by 238 wells $(3 \%)$ than in 2017 , while the average production drilling depth of new wells increased by 100 meters. Between 2010 and 2018, percentage of new wells put into production grew by $37 \%$ from 5802 wells in 2010 to 7946 wells in 2018. The average penetration depth of the wells increased by $22 \%$ : from 2848 meters in 2010 to 3478 meters in 2018 (Fig. 4).

New oil fields in Russia. On average, about 35.5 million tons of oil (about 7\%) annually fall on new fields in Russia, with a commissioning period of no more than 5 years, and in 2018 , the oil output of such fields reached its maximum value of 42 million tons over the period of 2010-2018 (Fig. 5).

In 2018, 54 new oil reservoirs were put into production, including the large fields of Russkoe, Tagulskoe and Kuyumba in the Krasnoyarsk Krai and Yamal-Nenets Autonomous Okrug.

In the last year, 625 production wells were placed into production in new fields with a commissioning period not longer than 5 years - the highest number for the period from 2010 to 2018. However, over the past 10 years, the average flow rate of wells in all fields decreased by $13 \%$, while the production drilling increased almost twice. Capital expenditures grew by 2.8 times, and the cost of producing one ton of oil-by 2.4 times. Nevertheless, new deposits are being put into operation, and their output keeps growing, reaching maximum values in the period under discussion.

\section{Prospects for changes in geography of the Russian oil industry}

Following the paradigm formulated by A. E. Kontorovich based on the strategy for changing the Arkhangelsky-Gubkin-Trofimuk geography of oil production, the structure of the mineral resource base is transformed, which defines a new

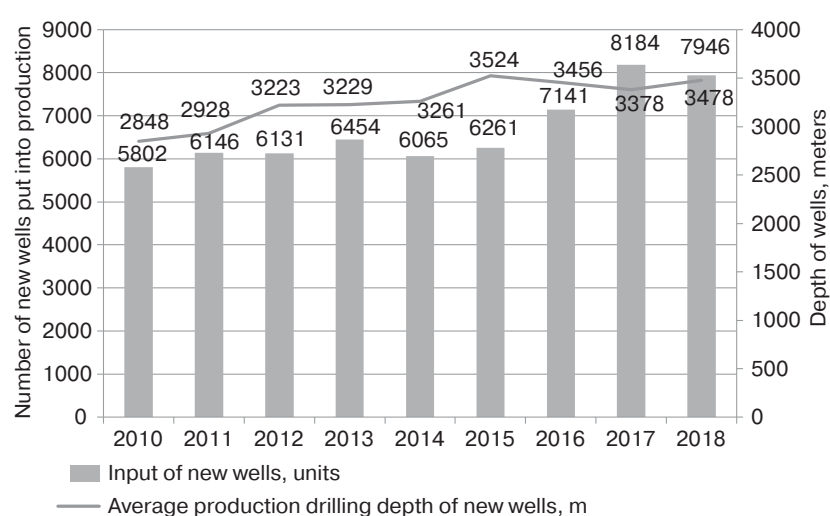

Fig. 4. Putting of new wells into production and average well depth

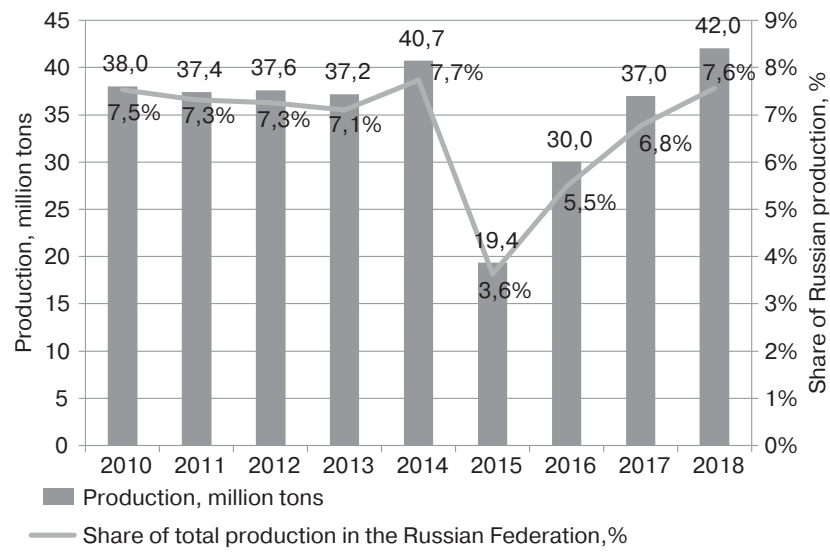

Fig. 5. Production in new oil fields with a commissioning period not longer than 5 years and percentage of the fields in the total oil production in the Russian Federation

paradigm for the development of the Russian oil industry for the long term. The main objects and top-priority tasks of oil prospecting, exploration and recovery will be [25]:

- sedimentary basins on the Russian shelf of the Arctic Ocean (Barents, Kara and Pechora seas);

- poorly studied oil and gas provinces in the east of the country (Lena-Tunguska oil and gas province);

- conventional oil reserves in the north of Western Siberia (Yamal-Nenets Autonomous Okrug, Gydan Peninsula, including the Ob and Taz Bay);

- tight oil reserves subject to development and creation of the search, appraisal, exploration and recovery technologies (Bazhenov, Abalak, Kuonam, Tyumen Formations, etc.);

- enhanced recovery of residual oil in the unique and large fields in the traditional areas of oil production;

- search, exploration and development of small and smallest pools in the mature oil and gas basins (Khanty-Mansi Autonomous Okrug, Tomsk Region, Republic of Tatarstan, Republic of Bashkortostan, Orenburg Region).

The existing oil resource base in most oil-producing regions of the country allows forecasting ambitious levels of oil production in fields not yet discovered. However, actual oil output will depend on preparedness of this resource base for development, i.e. on allocations, scope of exploration and increment in commercial quality reserves. In view of 
Forecast of oil production in Russia up to 2040 per oil and gas provinces, million tons (optimistic scenario, excluding condensate) [26]

\begin{tabular}{|l|c|c|c|c|c|c|c|}
\hline $\begin{array}{c}\text { Oil and gas } \\
\text { province }\end{array}$ & 2015 & 2020 & 2025 & 2030 & 2035 & 2040 & Total \\
\hline $\begin{array}{l}\text { West Siberian, } \\
\text { including the } \\
\text { left bank of the } \\
\text { Yenisei River }\end{array}$ & 320 & 331 & 330 & 393 & 414 & 428 & $\mathbf{8 4 3 9}$ \\
\hline Lena-Tunguska & 25 & 31 & 51 & 63 & 73 & 80 & $\mathbf{1 4 2 5}$ \\
\hline Timan-Pechora & 31 & 35 & 38 & 38 & 39 & 39 & $\mathbf{1 0 3 6}$ \\
\hline Volga-Ural & 116 & 109 & 96 & 78 & 63 & 51 & $\mathbf{2 2 4 8}$ \\
\hline $\begin{array}{l}\text { Northern } \\
\text { Caucasus }\end{array}$ & 2 & 2 & 3 & 3 & 3 & 3 & $\mathbf{7 6}$ \\
\hline Shelf & 14 & 21 & 34 & 40 & 48 & 49 & $\mathbf{9 4 5}$ \\
\hline $\begin{array}{l}\text { Russian } \\
\text { Federation }\end{array}$ & $\mathbf{5 0 8}$ & $\mathbf{5 2 9}$ & $\mathbf{5 5 2}$ & $\mathbf{6 1 5}$ & $\mathbf{6 4 0}$ & $\mathbf{6 5 0}$ & $\mathbf{1 4 1 6 9}$ \\
\hline
\end{tabular}

unfavorable pricing conditions on the world markets, oil companies primarily reduce investment in exploration.

Another important factor contributing to the growth of oil production in Russia in the long term is the development of technologies for the extraction of unconventional sources of hydrocarbons, especially oil from the Bazhenov Formation. In an optimistic scenario, it is possible to intensify the search, development and implementation of technologies for the efficient extraction of oil from sediments of the Bazhenov Formation.

As a result, the significant changes in the regional structure of oil production in Russia may occur in the coming decades. The share of oil production in the eastern regions and on the shelf of seas will almost triple. Oil production in the Lena-Tunguska province may increase from $4.8 \%$ in 2015 to $12 \%$ in 2040 (See Table). The share of sea shelves in the structure of oil production in Russia will increase from $2.8 \%$ in 2015 to $7.9 \%$ in 2040.

\section{Conclusion}

The main trend in the development of the world energy markets is the escalation of regional differentiation and interfuel competition. The development of the oil industry in Russia follows the world trends. The objective law of the oil and gas sector expansion in Russia is the change in the regional structure of oil production. Oil extraction geography shifts from west to east and northeast. New production regions feature harsh climatic conditions and low level of transport infrastructure, which necessitates promotion of the governmental support and stimulation of oil-producing companies.

At the same time, the analysis of the oil reserves and the current situation of the Russian oil industry allows anticipating an increase in the oil production in the country, subject to financing of exploration, expansion of transport and processing capacities, and development of tight oil production technologies. Western Siberia will retain the role of the main oil-producing center in Russia for the long term, despite the decline in oil output in the unique and large fields. In case of the beginning of large-scale reservoir development at the Bazhenov Formation and the discovery of new deposits, it is possible that oil production in this region stabilizes and grows.

Oil extraction will drop most rapidly in the Volga-Ural oil and gas province, where the depletion rate is one of the highest in the country. In some regions of the Volga-Ural oil and gas province, such as the Republics of Tatarstan and Bashkortostan, the small and smallest oil pools are already being actively put into development to maintain production at a stable level.

In Eastern Siberia within the Lena-Tunguska province, the increase in the oil production in the discovered fields is expected in 2040. The development of the Russian sector on the shelf of the Okhotsk, Caspian, Pechora and Barents Seas will continue due to discovered and prepared for industrial development deposits.

At the same time, in the long-term perspective, the oil industry will retain the role of the national economic advance driver and guarantor of fulfillment of social and international obligations at the regional and global levels.

\section{Acknowledgments}

The studies were supported by the Russian Science Foundation, Grant No. 17-78-20218: Spatial specialization and integrated development of mineral-producing regions.

The authors appreciate participation of L. V. Eder, Doctor of Economic Sciences, Professor, Chief Researcher of the Center for Oil and Gas Subsurface Management Economics at the Trofimuk Institute of Petroleum Geology and Geophysics, Siberian Branch, Russian Academy of Sciences these studies.

References

1. Kleshchev K. A., Lodzhevskaya M. I., Golov A. A. Basic parameters of the state of fuel-power sector of the countries - oil and gas producers. Gornyi Zhurnal. 2009. No. 3. pp. 18-24.

2. Antoninova N. Yu., Chaikina G. M., Rybnikova L. S., Shubina L. A. Geo-ecological problems of land and water use in the Urals deposits. Eurasian Mining. 2012. No. 1. pp. 44-47.

3. Ilyina G. F., Ilyin N. N. The issues of oil production and innovative development of the industry. Gornyi Zhurnal. 2012. Special Issue 4. pp. 7-9.

4. Prishchepa O. M., Teplov E. L., Senin S. V., Averyanova O. Yu. Non-traditional sources of hydrocarbon raw materials in Komi Republic. Gornyi Zhurnal. 2013. No. 9. pp. 53-56.

5. Linnik Yu. N., Afanasev V. Ya., Linnik V. Yu., Tretyakova M. V. Adaptive econometric models of short-term forecasting of oil price. Gornyi Zhurnal. 2014. No. 12. pp. 36-39.

6. Kryzhanivsky E. I., Kondrat R. M. Experience of final development of depleted oil and gas deposits. Gornyi Zhurnal. 2005. No. 5. pp. 79-83.

7. Goldman A. A., Tomsky K. O., Ivanova R. P. Perspectives of petroleum engineering education in Western Yakutia. Eurasian Mining. 2016. No. 1. pp. 55-59. DOI: 10.17580/em.2016.01.10

8. Rasche R. H., Tatom J. A. Energy Resources and Potential GNP. Federal Reserve Bank of St. Louis Review. 1977. Vol. 59, No. 6. pp. 10-24.

9. Rasche R. H., Tatom J. A. Energy Price Shocks, Aggregate Supply and Monetary Policy: The Theory and the International Evidence. Carnegie-Rochester Conference Series on Public Policy. 1981. Vol. 14. pp. 9-93.

10. Sachs J. D. The oil shocks and Macroeconomic adjustment in the United States. European Economic Review. 1982. No. 18. pp. 243-248.

11. Burbidge J. A., Harrison A. D. Testing for the effects of oil price rises using Vector Autoregressions. International Economic Review. 1984. Vol. 25, No. 2. pp. 459-484.

12. Bjornland H. C. The Dynamic Effects of Aggregate Demand, Supply and Oil Price Shocks - A Comparative Study. The Manchester School. 2000. No. 68. pp. 578-607. 
13. Rautava J. F. The Role of Oil Prices and the Real Exchange Rate on Russia's Economy. BOFIT Discussion Papers. 2002. No. 24. pp. 41-65.

14. Chuku C. A., Effiong E. J., Sam N. K. Oil price distortions and their short- and long-run impacts on the Nigerian economy. 2010. Available at: http://mpra.ub.uni-muenchen.de/24434/ (accessed: 24.06.2019)

15. Sachs J. D., Warner A. M. The Curse of Natural Resources. European Economic Review. 2001. Vol. 45. pp. 827-838.

16. Gylfason T. A. Natural Resources, Education, and Economic Development. European Economic Review. 2001. Vol. 45. pp. 847-859.

17. Alexeev M. V., Conrad R. J. The Elusive Curse of Oil. SAN Working Paper. 2005. No 7. pp. 201-229.

18. Stijns J.-P. C. Natural Resource Abundance and Economic Growth Revisited. Resources Policy. 2005. Vol. 30(2). pp. 107-130.

19. Brunnschweiler C. N. Cursing the Blessings? Natural Resource Abundance, Institutions, and Economic Growth. ETH Economics Working Paper. 2006. Vol. 51. pp. 83-101.

20. Polterovich V., Popov V., Tonis A. Mechanisms of the «resource curse» and economic policy. Voprosy Ekonomiki. 2007. No. 6. pp. 4-27.

21. Kontorovich A. E., Eder L. V., Filimonova I. V., Nikitenko S. M. Key Problems in the Development of the Power of Siberia
Project. Regional Research of Russia. 2018. Vol. 8, No. 1 pp. 92-100. DOI: 10.1134/S2079970518010057

22. Nikitenko S. M., Goosen E. V., Kontorovich A. E. Shift of the world energy sector development paradigm: Consequences for Russia. IOP Conference Series: Earth and Environmental Science. 2018. Vol. 206, No 1. pp. 120-153. DOI: 10.1088/1755$1315 / 206 / 1 / 012053$

23. Eder L. V., Komarova A. V., Filimonova I. V. et al. Sustainable development of resource regions on the declining stage of production: Innovative technologies and economic efficiency. IOP Conference Series: Earth and Environmental Science. 2018. Vol. 206, No. 1. pp. 110-119 DOI: 10.1088/1755-1315/206/1/012056

24. Eder L. V., Provornaya I. V., Filimonova I. V. Problems of Rational Use of Associated Petroleum Gas in Russia. Geography and Natural Resources. 2019. Vol. 40, No. 1. pp. 9-14. DOI: $10.1134 / \mathrm{S} 1875372819010025$

25. Filimonova I. V., Eder L. V., Komarova A. V., Provornaya I. V., Nemov V. Y. Resource regions of Russia: Socio-economic indicators and innovative development. IOP Conference Series: Earth and Environmental Science. 2018. Vol. 206, No. 1 pp. 97-104. DOI: 10.1088/1755-1315/206/1/012020

26. Kontorovich A. E., Eder L. V., Filimonova I. V., Mishenin M. V. The role of unique and large deposits in Russian oil sector: retrospective analysis, current state and forecast. Energeticheskaya politika. 2016. No. 2. pp. 34-43.

UDC 330.15

A. V. DUSHIN ${ }^{1}$, Rector, Doctor of Economic Sciences

M. N. IGNATYEVA ${ }^{1,2}$, Doctor of Economic Sciences, rinis@mail.ru

V. V. YURAK ${ }^{1,2}$, Associate Professor, Candidate of Economic Sciences

A. N. IVANOV ${ }^{1}$, Senior Lecturer

1 Ural state mining university, The Ural Branch of Russian Academy of Sciences, Yekaterinburg, Russia

2 Institute of Economics, The Ural Branch of Russian Academy of Sciences, Yekaterinburg, Russia

\section{ECONOMIC EVALUATION OF ENVIRONMENTAL IMPACT OF MINING: ECOSYSTEM APPROACH}

\section{Introduction}

Nowadays one of the main sources of environmental problems continues to be the mining sector, under the anthropogenic impact which hurts almost all elements of the biosphere. According to the authors' estimates [1], in the industry breakdown, the greatest damage of unit production is caused in the power industry and the coal industry. The proportion of damage caused by the production in mineral industries such as fuel, ferrous and nonferrous metallurgy is about $70 \%$ of the total damage impaired by pollution of the atmosphere and water bodies. Given the link between the level of economic advance, which is determined, first of all, by the development of the primary sector, and the degree of environmental pollution, we cannot expect improvement in the environmental situation, because mining today and in the foreseeable future is the unalienable necessity of mankind existence.

The Russian Strategy Concept of Socio-Economic Development until 2020 declares one of
The article considers the most important aspects of ecosystem approach implementation in mining. It requires the integrated economic assessment of the environmental consequences and the entire list of ecosystem services supplied by forest ecosystems most subjected anthropogenic impact of mineral mining. The authors identify the main ecosystem services supplied by forests and indirectly providing economic benefits to their consumers: maintenance of air composition in the atmosphere (carbon sequestration and oxygen production); air purification and water protection associated with an increase in precipitation and soil protection from erosion. The scientific novelty consists in the improvement of guidelines for economic assessment of ecosystem services generated by natural capital of the territories under consideration. The guidelines are developed for assessing the ecosystem service on air composition maintenance at various degree of detalization. The introduction of the decrease in precipitation due to rainfall retention by forest canopy in the economic assessment of water protection service is substantiated. The article systematizes approaches to economic assessment approaches of soil protection ecoservice, which allows selecting the most appropriate method for the specific conditions. The experience of using the discounting procedure in economic valuation of ecosystem services is summarized and analyzed.

Key words: mining, impact, consequences, economic assessment/evaluation, ecosystem services, economic damage.

DOI: $10.17580 /$ em.2020.01.06 